\title{
Studies on tracheorelaxant and anti-inflammatory activities of rhizomes of Polygonatum verticillatum
}

\author{
Haroon Khan ${ }^{1,24^{*}}$, Muhammad Saeed ${ }^{1}$, Malik Hassan Mehmood ${ }^{2}$, Najeeb-ur Rehman ${ }^{2,7}$, Naveed Muhammad ${ }^{1,8}$, \\ Ikram-ul Haq ${ }^{3}$, Nadeem Ashraf ${ }^{5}$, Kamal Eldin H El-Tahir ${ }^{6}$ and Anwarul-Hassan Gilani ${ }^{2}$
}

\begin{abstract}
Background: The present study describes the tracheorelaxant and anti-inflammatory effects of Polygonatum verticillatum which may support its medicinal use in hyperactive airway complaints and inflammatory disorders.

Methods: The tracheorelaxant activity of crude extract of the rhizomes of $P$. verticillatum (PR) was assessed in isolated guinea-pig tracheal tissues immersed in tissue organ bath filled with Tyrode's solution and a continuous supply of carbogen gas $\left(95 \% \mathrm{O}_{2}\right.$ and $\left.5 \% \mathrm{CO}_{2}\right)$. The contractile and relaxant responses of the tissue were measured using isometric transducers coupled with Power-Lab data acquisition system. The anti-inflammatory effect was evaluated in carrageenan-induced rat paw edema model, while the lipoxygenase inhibitory activity was performed in the in-vitro assay. Various chromatographic and spectroscopic techniques were used for the isolation and characterization of pure molecules.

Results: In isolated guinea-pig tracheal preparations, PR caused complete inhibition of the high $\mathrm{K}^{+}(80 \mathrm{mM})$ and carbachol-induced contractions however, it was more potent against $\mathrm{K}^{+}$than $\mathrm{CCh}$, similar to verapamil. Pretreatment of the tissue with PR, displaced the $\mathrm{Ca}^{2+}$ concentration-response curves to the right, similar to that induced by verapamil, indicating the presence of $\mathrm{Ca}^{2+}$ channel blocking like activity. When tested on carrageenaninduced rat paw edema, PR demonstrated a marked reduction in edema with $65.22 \%$ protection at $200 \mathrm{mg} / \mathrm{kg}$, similar to aspirin. In the in-vitro assay, PR showed lipoxygenase inhibitory activity $\left({ } C_{50}: 102 \pm 0.19 \mu \mathrm{g} / \mathrm{mL}\right)$, similar to baicalein. Bioactivity-guided fractionation led to the isolation of 2-hydroxybenzoic acid and $\beta$-sitosterol.

Conclusions: These results indicate that the plant possesses tracheorelaxant, mediated possibly through a $\mathrm{Ca}^{2+}$ channel blockade mechanism, and anti-inflammatory activities, which may explain the medicinal use of this plant in airway disorders and inflammation.
\end{abstract}

Keywords: Polygonatum verticillatum, Bronchodilator, $\mathrm{Ca}^{2+}$ antagonist, Anti-inflammatory, 2- Hydroxybenzoic acid, $\beta$-sitosterol

\section{Background}

Polygonatum verticillatum [L.] All. (Nooreallam) belonging to family Liliaceae or Convallariaceae possesses around 57 species and is commonly found in East Asia, China and Japan [1,2]. In different traditional systems of medicine, Polygonatum is popular for its use in pulmonary disorders like asthma and inflammation $[3,4]$, in addition to its multiple other health benefits such as, antituberculant, antidiabetic, antihypertensive, diuretic,

\footnotetext{
* Correspondence: hkdr2006@gmail.com

'Department of Pharmacy, University of Peshawar, Peshawar 25120, Pakistan ${ }^{2}$ Natural Product Research Division, Department of Biological and Biomedical Sciences, The Aga Khan University Medical College, Karachi 74800, Pakistan Full list of author information is available at the end of the article
}

analgesic and antipyretic activities [4,5]. P. verticillatum has also been studied for its analgesic [6,7], antimalarial and antioxidant [8], metal accumulant [9], insecticidal [10], antibacterial [11] and antipyretic [12] activities.

A variety of phytochemical constituents have been isolated from different species of the genus Polygonatum; primarily: saponins, alkaloids, glycosides, flavonoids and phytohormones. These groups of compounds show different types of activities. Long chain esters from this plant exhibit potent tyrosinase inhibition [13], alkaloid, homoisolflavanone, triterpenoid and steroidal saponin show profound antimicrobial and anticancer properties [14-17] and emodin from Polygonatum has shown

\section{Ciomed Central}


ameliorating effects on the memory consolidation [18]. Several compounds have also been isolated from the rhizomes of $P$. verticillatum including lectins [19], 5hydroxymethyl-2-furaldehyde and diosgenin [8]. There is no study to the best of our knowledge reporting its usefulness in hyperactive airways disorders or inflammation. This study describes the tracheorelaxant and antiinflammatory activities of $P$. verticillatum to provide a scientific background to its medicinal use in hyperactive airways complaints like asthma or inflammatory conditions. The in-vivo and in-vitro experimental studies have been designed, followed by bioactivity-guided isolation of its secondary metabolites.

\section{Method}

\section{Plant material}

$P$. verticillatum (whole plant) was collected from the District Swat, Khyber Pukhtonkhawa, Pakistan, in JulyAug 2007. The botanical characterization of the plant material was executed by the Taxonomy Department of PCSIR Laboratories Peshawar and a specimen with catalogue No: 9970 (PES) was deposited in the herbarium of PCSIR Laboratories Peshawar.

\section{Plant extraction}

Air-shade dried rhizomes of the $P$. verticillatum $(8 \mathrm{~kg})$ were grounded to a fine powder. The powdered material was soaked in aqueous-methanol (30:70) for three days while shaking occasionally [20] and filtered through a muslin cloth and Whatman filter paper (Maidstone, UK) simultaneously. This procedure was repeated three times and all the pooled filtrates were evaporated on a rotary evaporator (model RE-111, Buchi, Flawil, Switzerland) under reduced pressure $(-760 \mathrm{~mm} \mathrm{Hg})$ to obtain a dark greenish semi-solid material, yielding $27.50 \mathrm{wt} / \mathrm{wt} \%$.

\section{Experimental animals}

A total of thirty Wistar rats (190-260 g) and five adult local guinea-pigs $(1.2-1.6 \mathrm{~kg})$ of either sex were kept under standard laboratory conditions at $25 \pm 2{ }^{\circ} \mathrm{C}$ and a relative humidity of $40-70 \%$. The light cycle was maintained as $12 \mathrm{~h}$ dark: $12 \mathrm{~h}$ light. They were fed with a laboratory diet ad libitum and allowed free access to drinking water. All the experiments were performed in compliance with the rulings of the Institute of Laboratory Animal Resources, Commission on Life Sciences, National Research Council [21] and approved by the local Ethical Committee of the Karachi University.

\section{Drugs and reagents}

Carrageenan, carbachol ( $\mathrm{CCh})$, verapamil hydrochloride, soybean lipoxygenase, linoleic acid sodium salt and baicalein were purchased from the Sigma Chemicals Co., St. Louis, MO, USA and aspirin was obtained from the
Reckitt \& Colman, Pakistan. Chemicals used for making Tyrode's solution were: potassium chloride (Sigma Chemicals Co., St. Louis, MO, USA), calcium chloride, glucose, magnesium chloride, sodium bicarbonate, sodium dihydrogen phosphate (Merck, Darmstadt, Germany) and sodium chloride from BDH Laboratory supplies, Poole, England. All chemicals used were of highest grade available, and were solubilized in distilled water/saline while carrageenan was used as suspension with acacia.

\section{Isolated guinea-pig tracheal tissue}

The trachea was obtained from guinea-pigs and preserved in physiological solution (Kreb's solution). Rings containing a couple of cartilages were formed from a tracheal tube approximately $2-3 \mathrm{~mm}$ wide. Rings were cut into strips by a longitudinal cut on the ventral side reverse to the smooth muscle [22]. The strips were suspended in a tissue bath $(20 \mathrm{~mL})$ containing Kreb's solution ( $\mathrm{pH} 7.4$ ), maintained at $37^{\circ} \mathrm{C}$ and aerated with a mixture of $95 \%$ oxygen and $5 \%$ carbon dioxide (carbogen). Tracheal strips were maintained at 1 gram constant tension during the course of experiment. The tissues were granted $1 \mathrm{~h}$ to equilibrate prior to the introduction of test material. Before determining the inhibitory activity of the plant extract, the isolated tracheal tissues were stabilized with high $\mathrm{K}^{+}(80 \mathrm{mM})$ and $\mathrm{CCh}$ $(1 \mu \mathrm{M})$ until constant responses of each agonist were achieved (usually 3-4 concentrations). The sustained contractions were obtained using $\mathrm{CCh}$ and $\mathrm{K}^{+}$separately and the inhibitory effect was assessed using the cumulative addition of the test material. Isometric responses were recorded on a Grass model 7 Polygraph (Grass instrument company, Quincy, MA, USA). The inhibition of the high $\mathrm{K}^{+}$-induced contractions indicates $\mathrm{Ca}^{2+}$ antagonist activity [23], which was confirmed by constructing the $\mathrm{Ca}^{2+}$ concentration-response curves in the absence and presence of increasing concentrations of the plant material.

\section{Carrageenan-induced edema}

The carrageenan-induced rat hind paw edema test was conducted as described previously [24]. The test animals were divided in to five groups $(n=6)$. Group I (the control group) received normal saline $(10 \mathrm{~mL} / \mathrm{kg})$. The rats of group II, III and IV received the test extract (50, 100 or $200 \mathrm{mg} / \mathrm{kg}$ i.p.), while, group V (positive control) received aspirin $(100 \mathrm{mg} / \mathrm{kg}$ i.p.). Following $30 \mathrm{~min}$ of the treatments, acute inflammation was induced by subplantar injection of $0.1 \mathrm{~mL}$ of $1 \%$ suspension of carrageenan with $2 \%$ gum acacia in normal saline, in the right hind paw of the rats. The paw volume was estimated with the help of plethysmometer (Ugo Basile, Italy) at $1^{\text {st }}, 2^{\text {nd }}, 3^{\text {rd }}, 4^{\text {th }}$ and $5^{\text {th }} \mathrm{h}$ after the carrageenan injection. Statistics was applied on the raw data for the calculation 
of reduction in rat paw volume $(\mathrm{mL})$ for each group against saline, followed by the calculation of percent reduction in the rat paw using the following formula:

$\%$ inhibition $=1-(\mathrm{dt} / \mathrm{dc}) \times 100$

where "dt" is the difference in paw volume in the treated group and "dc" the difference in paw volume in the control group.

\section{Soybean lipoxygenase inhibitory assay}

The lipoxygenase (LOX) inhibition assay was conducted by using different dilutions of the PR by following previously described method [25]. Soybean lipoxygenase and linoleic acid were used. Equal volume $(10 \mathrm{~mL})$ of the sample (PR) and standard drug along with $20 \mathrm{~mL}$ of solvent lipoxygenase solution simultaneously were mixed followed by incubation for $5 \mathrm{~min}$ at $25^{\circ} \mathrm{C}$. The biochemical reaction was initiated by the addition of linoleic acid solution $(10 \mu \mathrm{L})$ as substrate and the absorption change with the formation of (9Z,11E)-13S)-13-hydroperoxyoctadeca-9, 11-dienoate was followed for $10 \mathrm{~min}$ at $234 \mathrm{~nm}$. The test sample and the control were dissolved in $50 \%$ ethanol. All the reactions were performed in triplicate. Baicalein was used as a positive control. The median effective concentrations ( $\mathrm{IC}_{50}$ values) were calculated using the EZ-Fit Enzyme Kinetics program (Perrella Scientific Inc., Amherst, USA).

\section{Isolation of pure molecules}

A sample of $80 \mathrm{~g}$ of the aqueous-methanol extract of $P$. verticillatum rhizomes (PR) was subjected to column chromatography over silica gel (column grade) for the isolation of pure chemical compounds. The sample was loaded in a glass column over silica gel for adsorption that acts as stationary phase. The column was initiated with $100 \% n$-Hexane as eluent (mobile phase). Polarity of mobile phase was enhanced gradually with regular monitoring of the isolate status over TLC, it resulted in 12 sub-fractions (P1-P12). Similar with methanol/chloroform gradient, 9 subfractions (M1-M9) were obtained. When sub-fraction P9 was purified through column chromatography, 2-Hydroxybenzoic acid (A) was isolated in the colorless crystals form (1A). Subfraction P11 was re-chromatographed over silica gel. While eluting with chloroform: hexane; (8:2), $\beta$-Sitosterol (B) was isolated as colorless amorphous powder (1B).

\section{Characterization of 2-Hydroxybenzoic acid (A)}

Colorless crystals, M.P. $159-160^{\circ} \mathrm{C}$, HREIMS: $m / z 138$ (Calcd. for $\left.\mathrm{C}_{7} \mathrm{H}_{6} \mathrm{O}_{3} ; 138.12\right),{ }^{1} \mathrm{H}$ NMR $\left(\mathrm{CHCl}_{3}, 300 \mathrm{MHz}\right)$ : $\delta 6.89$ broad d $(J=8.4 \mathrm{~Hz}), 7.42 \mathrm{dt}(J=1.8,8.4 \mathrm{~Hz}), 6.85 \mathrm{t}$ $(J=7.8 \mathrm{~Hz}), 7.83$ dd $(J=1.8,8.4),{ }^{13} \mathrm{C} \mathrm{NMR}\left(\mathrm{CDCl}_{3}\right.$,
$75 \mathrm{MHz}): \delta 113.9$ (C-1), 163.2 (C-2), 118.1 (C-3), 136.6 (C-4), 120.0 (C-5), 131.5 (C-6), 173.5 (C-1').

\section{Characterization of $\beta$-sitosterol (B)}

Colourless amorphous powder, M.P. $135-136^{\circ} \mathrm{C}$, HREIMS: $m / z \quad 414.3845$ (calculated for $\mathrm{C}_{29} \mathrm{H}_{50} \mathrm{O}$ as 414.3855). ${ }^{1} \mathrm{H}$ NMR $\left(\mathrm{CHCl}_{3}, 300 \mathrm{MHz}\right): \delta 3.65(\mathrm{~m}), 5.35(\mathrm{~m}), 0.67(\mathrm{~s})$, 0.99 (s), $0.91 \mathrm{~d}(J=6.3 \mathrm{~Hz}), 0.83 \mathrm{~d}(J=6.8 \mathrm{~Hz}), 0.79 \mathrm{~d}$ $(J=6.8 \mathrm{~Hz}), 0.82 \mathrm{t}(J=7.0 \mathrm{~Hz}) \cdot{ }^{13} \mathrm{C} \mathrm{NMR}\left(\mathrm{CDCl}_{3}\right.$, $75 \mathrm{MHz}): \delta 37.1$ (C-1), 31.6 (C-2), 72.1 (C-3), 42.4 (C-4), 139.5 (C-5), 120.0 (C-6), 32.5 (C-7), 35.3 (C-8), 49.8 (C-9), 36.2 (C-10), 22.1 (C-11), 40.3 (C-12), 43.1 (C-13), 56.9 (C-14), 24.7 (C-15), 27.9 (C-16), 54.7 (C-17), 12.1 (C-18), 18.7 (C-19), 40.1 (C-20), 21.5 (C-21), 33.8 (C-22), 28.8 (C-23), 50.5 (C-24), 26.7 (C-25), 18.9 (C-26), 21.5 (C-27), 23.1 (C-28), 12.6 (C-29).

\section{Statistical analysis}

Results obtained from the pharmacological experiments are expressed as mean values \pm S.E.M. One-way ANOVA test was employed for comparison of the significant differences among the groups followed by Dunnet's multiple comparison post-test. A probability of $P<0.05$ was considered as significant. Concentration-response curves were analyzed by nonlinear regression using GraphPad program (GraphPAD, San Diego, CA, USA).

\section{Results \\ Effect of PR on guinea-pig tracheal tissue}

When PR was studied for its inhibitory effect against high $\mathrm{K}^{+}(80 \mathrm{mM})$ and $\mathrm{CCh}(1 \mu \mathrm{M})$ induced contractions in guinea-pig tracheal preparations, it caused inhibitory effects at the dose range of $0.01-10 \mathrm{mg} / \mathrm{mL}$ in a dosedependent manner with greater potency against $\mathrm{K}^{+}$ (Figure 1a), similar to that of verapamil, which exhibited relaxation at the dose range of $0.03-3 \mu \mathrm{M}$ (Figure 1c).

To confirm the $\mathrm{Ca}^{2+}$ antagonist-like effect, the concentration-response curves (CRCs) of $\mathrm{Ca}^{2+}$ were constructed in the absence and presence of different doses of the plant extract, in $\mathrm{Ca}^{2+}$-free and $\mathrm{K}^{+}$rich medium. Pretreatment of PR at the doses of 0.03 and $0.1 \mathrm{mg} / \mathrm{mL}$, displaced the CRCs of $\mathrm{Ca}^{2+}$ to the right with suppression of the maximum response (Figure 1b), similar to that caused by verapamil, which also displaced the $\mathrm{Ca}^{2+}$ CRCs to the right with suppression of the maximum response at tested doses of 0.003 and $0.01 \mu \mathrm{M}$ (Figure 1d).

\section{Effects of PR on carrageenan-induced rat paw edema}

PR demonstrated marked reduction $(P<0.01)$ in edema showing anti-inflammatory activity at the test doses of 50,100 and $200 \mathrm{mg} / \mathrm{kg}$, similar to that caused by aspirin (Table 1). The data show that the effect is dose and time-dependent with a peak effect obtained after $3 \mathrm{~h}$ of 

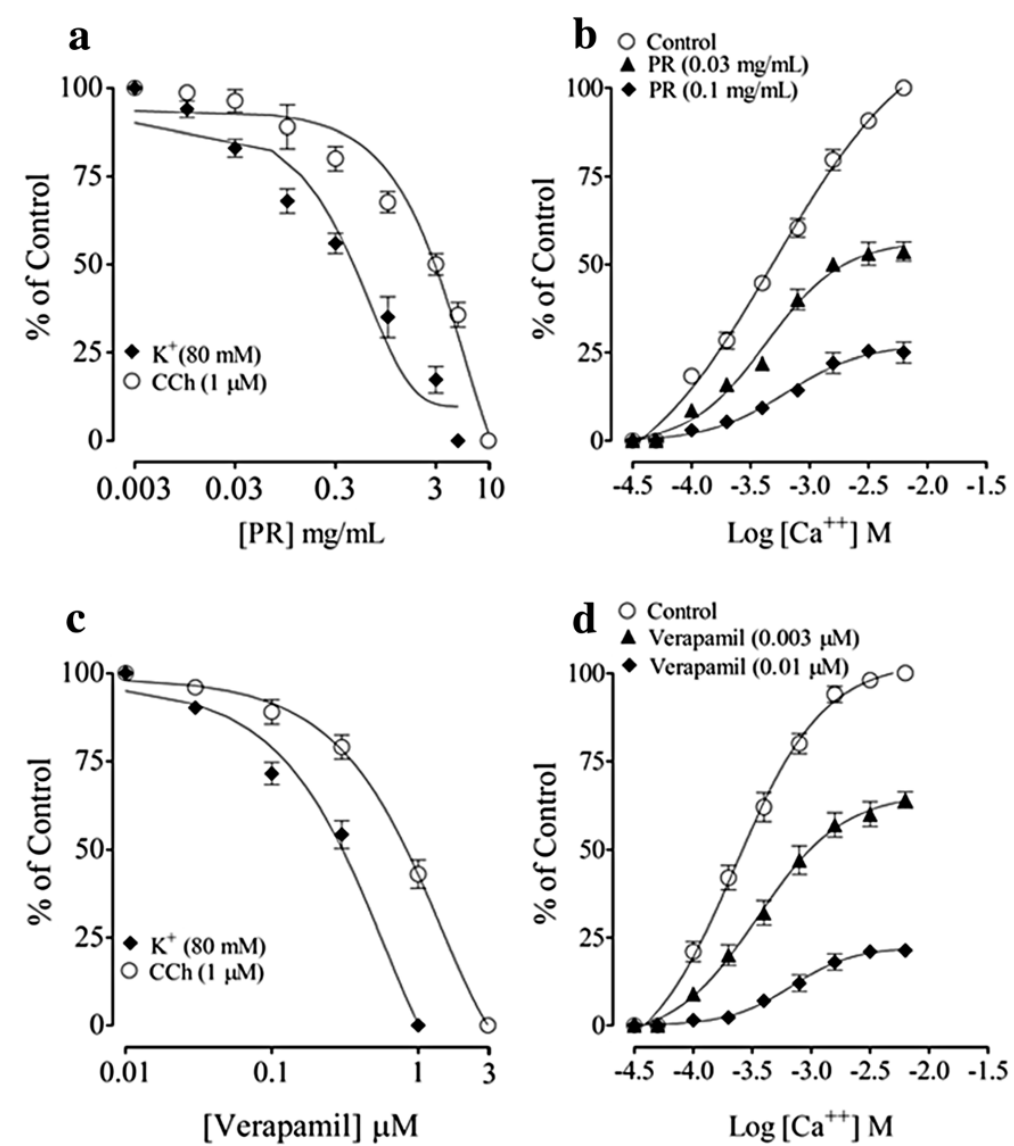

Figure 1 Dose-dependent inhibitory effect of the aqueous-methanol extract of $P$. verticillatum Rhizomes, PR (a) and verapamil (c) on carbachol $(\mathrm{CCh})$ and $\mathrm{K}^{+}(80 \mathrm{mM})$-induced contractions, and the dose-response curves of $\mathrm{Ca}^{2+}$ created in the absence and presence of increasing concentrations of PR (b) and verapamil (d) in isolated guinea-pig jejunum preparation. Data stand for mean \pm SEM of 3-5 different experimental findings.

administration of PR $(200 \mathrm{mg} / \mathrm{kg})$, similar to the effect of aspirin.

\section{Effect of PR on lipoxygenase activity}

When tested for inhibition of soybean lipoxygenase by the UV absorbance based enzyme assay, PR showed a significant activity against lipoxygenase with resultant $\mathrm{IC}_{50}$ value of $102 \pm 0.19 \mu \mathrm{g} / \mathrm{mL} \quad($ mean \pm SEM, $\mathrm{n}=3$ ) compared with that of the standard drug, baicalaim $(22.6 \pm 0.09 \mu \mathrm{g} / \mathrm{mL}, \mathrm{n}=3)$.

\section{Isolation of pure molecules}

The structures of isolated molecules, 2-hydroxybenzoic acid (a) and $\beta$-sitosterol (b) were confirmed by mass and NMR spectral data available in literature $[26,27]$ and shown in Figure 2.

Table 1 Anti-inflammatory effect of the aqueous-methanol extract of $P$. verticillatum Rhizomes (PR) in carrageenan-induced hind paw edema in rats

\begin{tabular}{|c|c|c|c|c|c|c|}
\hline \multirow[t]{2}{*}{ Group } & \multirow{2}{*}{$\begin{array}{l}\text { Dose } \\
\mathrm{mg} / \mathrm{kg}\end{array}$} & \multicolumn{5}{|c|}{ Increase in paw volume (Mean \pm SEM) in $\mathrm{mL}$} \\
\hline & & $1 \mathrm{~h}$ & $2 \mathrm{~h}$ & $3 \mathrm{~h}$ & $4 \mathrm{~h}$ & $5 \mathrm{~h}$ \\
\hline Saline & 10 & $0.70 \pm 0.031$ & $0.69 \pm 0.040$ & $0.69 \pm 0.049$ & $0.70 \pm 0.067$ & $0.72 \pm 0.053$ \\
\hline \multirow[t]{3}{*}{ PR } & 50 & $0.64 \pm 0.045(08.57 \%)$ & $0.61 \pm 0.054(11.59 \%)$ & $0.55 \pm 0.049(20.29 \%)$ & $0.54 \pm 0.053(22.85 \%)$ & $0.55 \pm 0.049(23.61 \%)$ \\
\hline & 100 & $0.56 \pm 0.036(20.00 \%)$ & $0.50 \pm 0.049^{*}(27.53 \%)$ & $0.37 \pm 0.058^{* *}(46.37 \%)$ & $0.39 \pm 0.062^{* *}(44.29 \%)$ & $0.47 \pm 0.062^{*}(34.72 \%)$ \\
\hline & 200 & $0.47 \pm 0.040^{*}(32.86 \%)$ & $0.35 \pm 0.067^{* *}(49.27 \%)$ & $0.24 \pm 0.045^{* *}(65.22 \%)$ & $0.31 \pm 0.053^{* *}(55.71 \%)$ & $0.34 \pm 0.062^{* *}(52.78 \%)$ \\
\hline Aspirin & 100 & $0.23 \pm 0.040^{* *}(67.14 \%)$ & $0.19 \pm 0.017^{* *}(72.46 \%)$ & $0.17 \pm 0.031^{* *}(78.1 \%)$ & $0.18 \pm 0.022^{* *}(75.71 \%)$ & $0.18 \pm 0.036^{* *}(75.00 \%)$ \\
\hline
\end{tabular}

Experimental data are expressed as mean \pm S.E.M. for group of at least six animals. One- way ANOVA was utilized as judgment test of significant differences among groups followed by Dunnett's multiple comparison post-test. A probability of ${ }^{*} P<0.05$ or ${ }^{* *} P<0.01$ was considered significant from control. Protection (\%) is shown in parenthesis. 


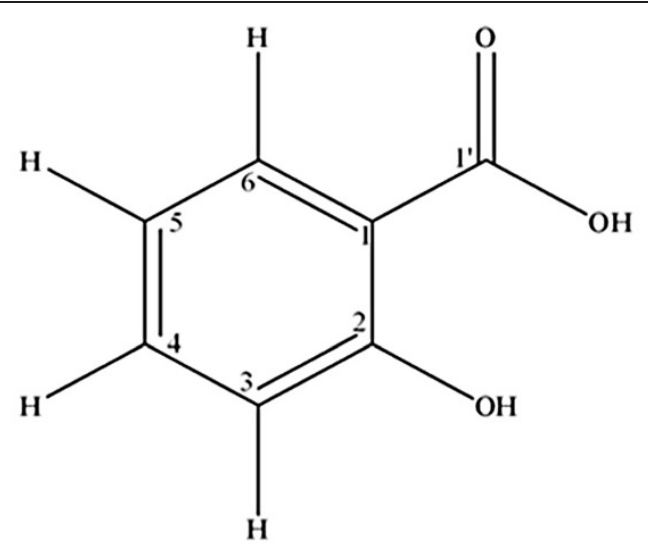

$\mathbf{a}$

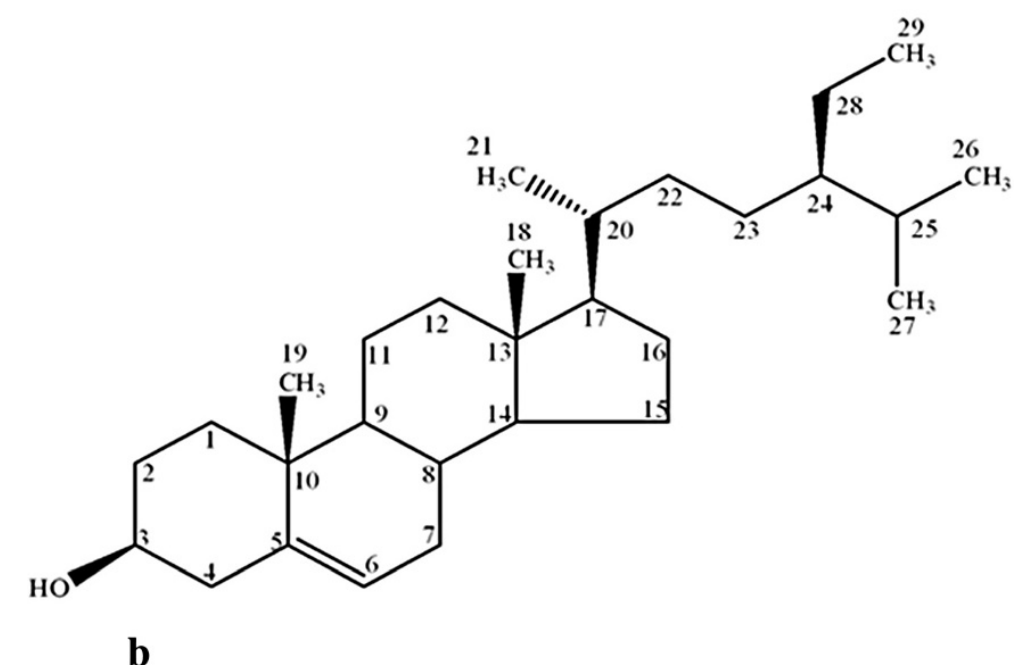

Figure 2 Structures of isolated compounds (a) 2-hydroxybenzoic acid, (b) $\beta$-sitosterol.

\section{Discussion}

In view of its medicinal use in hyperactive airway disordered like bronchial spasms and asthma [3], P. verticillatum has been studied for its myorelaxant activity using isolated guinea-pig tracheal tissue preparations. While on the basis of its folk reputation as an antiinflammatory remedy [4], the plant has been tested for its anti-inflammatory potential using carrageenan-induced rat paw edema model.

When test for tracheorelaxant activity, $P$. verticillatum caused relaxation of high $\mathrm{K}^{+}$and $\mathrm{CCh}$-induced contractions in isolated guinea-pig tracheal tissues with greater potency against $\mathrm{K}^{+}$. The smooth muscle contraction of different body systems including the airways depends upon an increase in the cytoplasmic free $\mathrm{Ca}^{2+}$, which activates the cellular contractile machinery. The increase in intracellular $\mathrm{Ca}^{2+}$ is due to either influx via voltage-dependent $\mathrm{Ca}^{2+}$ channels (VDCs) or release from intracellular stores in the sarcoplasmic reticulum. At concentrations higher than $30 \mathrm{mM}, \mathrm{K}^{+}$is known to cause smooth muscle contractions through the opening of VDCs, consequently allowing inward movement of extracellular $\mathrm{Ca}^{2+}$ originating a contractile effect; thus, a substance causing inhibition of high $\mathrm{K}^{+}$-induced contraction is considered as an inhibitor of $\mathrm{Ca}^{2+}$ influx [23]. Similar to the pattern of inhibitory effect of verapamil, a standard $\mathrm{Ca}^{2+}$ antagonist [28], against $\mathrm{K}^{+}$and $\mathrm{CCh}$, a substance causing inhibition of high $\mathrm{K}^{+}$at low concentrations than its effect on $\mathrm{CCh}$, may indicate the presence of $\mathrm{Ca}^{2+}$ antagonist-like spasmolytic mechanism. To confirm the $\mathrm{Ca}^{2+}$ antagonist-like effect of $P$. verticillatum, the concentration-response curves (CRCs) of $\mathrm{Ca}^{2+}$ were constructed in the absence and presence of different doses of the plant extract, where it displaced the CRCs of $\mathrm{Ca}^{2+}$ to the right with suppression of the maximum response similar to the effect produced by verapamil, thus attesting the presence $\mathrm{Ca}^{2+}$ antagonist-like constituents in the plant extract. The $\mathrm{Ca}^{2+}$ antagonists are known to possess therapeutic potential in the management of hyperactive airways disorders $[29,30]$. Thus, the $\mathrm{Ca}^{2+}$ antagonist effect 
observed in this study may explain the medicinal use of the plant in airways disorders, though additional mechanism cannot be ruled out.

The carrageenan-induced paw edema test is a wellestablished animal model of inflammation used to detect the anti-inflammatory activity of test materials [25]. It has been observed that the local edema is induced by the sub-plantar injection of carrageenan that increases progressively. Edema formation due to carrageenan injection in the rat paw is the biphasic event during $1-5 \mathrm{~h}$; the initial phase ( 1 to $1.5 \mathrm{~h}$ ) is predominately a nonphagocytic edema followed by a second phase with increased edema formation that persists up to $5 \mathrm{~h}[31,32]$. Different mediators are known to be involved in different stages of carrageenan-induced edema. The initial phase (up to $1.5 \mathrm{~h}$ ) is attributed to the release of histamine, 5-hydroxytryptamine, bradykinin, platelet activating factor and serotonin. Kinins (bradykinin and kallikrein) are involved in both stages, and get released from 1.5 to $2.5 \mathrm{~h}$ and at the last step inflammation is continued until $5 \mathrm{~h}$ due to the release of lipid derived eicosanoids (prostaglandins, leukotrienes, hydroperoxyeicosatetraenoic acid). A comprehensive phagocytic inflammation is observed at $3^{\text {rd }} \mathrm{h}$ followed by carrageenan injection with large number of neutrophils and tissue edema [25,31]. Our results showed significant $(P<0.01)$ inhibition in carrageenan-induced paw edema model at all test doses of anti-inflammatory activity of $P$. verticillatum with maximum effect at $3^{\text {rd }} \mathrm{h}$. The observed anti-inflammatory activity provides an evidence to the folkloric use of $P$. verticillatum in inflammation.

Leukotrienes (LTs) are the downstream products of arachidonic acid that exert pivotal biological functions as well as pathogenic effects in a wide range of inflammatory processes. Polymorphonuclear leukocytes and monocytes/macrophages are the major cells capable of synthesizing LTs due to a high 5-Lipoxygenase activity and represent crucial components in chronic inflammatory diseases [33-35]. The role of lipoxygenase is also documented in carrageenan provoked edema [33]. Inhibition of lipoxygenase activity results in down regulation of the pro-inflammatory activity of leukocytes and platelets [36], which may cause a diminished or delayed outcome of the inflammatory reaction. From a mechanistic point of view, PR elicited marked inhibitory activity in soybean lipoxygenase assay.

Phytochemically, the isolation of 2-hydroxybenzoic acid and $\beta$-sitosterol strengthened our findings in a way that the anti-inflammatory and antioxidant potential of these compounds have been previously investigated [37-39]; the effect of 2-hydroxybenzoic acid is known to be mediated through lipoxygenase (LOX)/cyclooxygenase (COX) inhibition [40,41]. Keeping this in view, it can also be speculated that the mechanism underlying the anti-inflammatory activity of $P$. verticillatum is at least in part due to LOX/COX inhibition, however the additional mechanism cannot be ruled out which may be responsible for the effectiveness of this plant in hyperactive airways disorders.

Free radical generation plays a pivotal role in the pathophysiology of inflammatory and airways disorders $[42,43]$. P. verticillatum is known to possess strong antioxidant activity [8], which is likely to complement the anti-inflammatory potential of this plant. Similarly, $\beta$ sitosterol is known to possess the $\mathrm{Ca}^{2+}$ channel blocking activity [22], which is again consistent with our findings, showing $\mathrm{Ca}^{2+}$ antagonist activity of $P$. verticillatum.

There is paucity in traditional literature regarding exact dose of the plant recommended to be used in airways disorders or as an external anti-inflammatory agent; however, the observed effective doses were selected on the basis of our experience of studying the possible mode of actions of natural remedies for their effectiveness in airways disorders and inflammatory conditions [12,44-46].

\section{Conclusions}

These data indicate that $P$. verticillatum possesses tracheorelaxant, mediated possibly through the $\mathrm{Ca}^{2+}$ channel blockade and anti-inflammatory activities, which may explain the medicinal use of this plant in airway disorders and inflammatory complaints. However, detailed studies are warranted to ascertain the clinical significance of this natural product.

\section{Competing interests}

The authors declare that they have no competing interests.

\section{Authors' contributions}

MS, AHG and KEHET designed the project, supervised the study and draft the final version of manuscript. NR, IKH and NM helped in the draft, experimental work, data collection and evaluation, literature search and manuscript preparation. MHM helped in study design, analysis of data and preparation of manuscript draft. HK and NA carried out experimental work and prepared initial draft of the manuscript All authors read and approved the final manuscript for publication.

\section{Acknowledgements}

This study was supported in part by the Pakistan Science Foundation. We would like to thank Dr. Ruqaiyyah Siddiqui, DBBS of the Aga Khan University, for language correction. AH Gilani is a visiting Professor at the King Saud University (KSU), Riyadh, Saudi Arabia.

\section{Author details}

${ }^{1}$ Department of Pharmacy, University of Peshawar, Peshawar 25120, Pakistan. ${ }^{2}$ Natural Product Research Division, Department of Biological and Biomedical Sciences, The Aga Khan University Medical College, Karachi 74800, Pakistan.

${ }^{3}$ National Institute of Health, Islamabad 45500, Pakistan. ${ }^{4}$ Gandhara College of Pharmacy, Gandhara University, Peshawar, Pakistan. ${ }^{5}$ Molecular Brain Research Group, Robarts Research Institute, Department of Physiology \& Pharmacology, Faculty of Medicine, University of Western Ontario, 100 Perth Drive, London, ON N6A 5K8, Canada. ${ }^{6}$ Department of Pharmacology, College of Pharmacy, King Saud University, Riyadh, Saudi Arabia. ${ }^{7}$ Department of Basic Medical Sciences, Faculty of Pharmacy, Gomal University, D.I. Khan-29050, Khyber-Pakhtoonkha, Pakistan. ${ }^{8}$ Department of Pharmacy, Hazara University, Havelian Campus, Abbottabad, Pakistan. 
Received: 10 August 2012 Accepted: 26 July 2013

Published: 29 July 2013

\section{References}

1. Tamura MN: Biosystematic studies on the genus polygonatum (liliaceae) 111. Morphology of staminal filaments and karyology of elevan Eusasian species. Botanische Jahrbücher für Systematik 1993, 115:1-26.

2. Monika S, Jakub S, Kornelia P, Czeslaw H, Roman Z: Comparison of three Polygonatum species from Poland based on DNA markers. Ann Bot Fennici 2006, 43:378-388.

3. Jiang S: Dictionary of Chinese herbal medicines. Shanghai: Shanghai People's Publishing Press; 1977:2041-2044.

4. Duke JA, Bogenschutz-Godwin MJ, Du Celliar J, Duke PAK: Handbook of medicinal herbs. Boca Raton FL: CRC Press; 2002:683.

5. Singh AP: Ashtavarga-rare medicinal plants. Ethnobot Leaflets 2006, 10:104-108

6. Khan H, Saeed M, Gilani AH, Khan MA, Dar A, Khan I: The antinociceptive activity of Polygonatum verticillatum rhizomes in pain models. J Ethnopharmacol 2010, 127:521-527.

7. Khan H, Saeed M, Gilani AH, Khan MA, Khan I, Ashraf N: Anti-nociceptive activity of aerial parts of polygonatum verticillatum: attenuation of both peripheral and central pain mediators. Phytother Res 2011, 25:1024-1030

8. Khan H, Saeed M, Khan MA, Khan I, Ahmad M, Muhammad N, Khan A Antimalarial and free radical scavenging activities of rhizomes of Polygonatum verticillatum supported by isolated metabolites. Med Chem Res 2011, 21:1278-1282.

9. Saeed M, Khan H, Khan MA, Khan F, Khan SA, Muhammad N: Quantification of various metals accumulation and cytotoxic profile of aerial parts of Polygonatum verticillatum. Pak J Bot 2010, 42:3995-4002.

10. Saeed M, Khan H, Khan MA, Simjee SU, Muhammad N, Khan SA: Phytotoxic, insecticidal and leishmanicidal activities of aerial parts of Polygonatum verticillatum. Afri J Biotech 2010, 9:1241-1244.

11. Khan H, Saeed M, Muhammad N, Ghaffar R, Khan SA, Hassan S: Antimicrobial activities of rhizomes of Polygonatum verticillatum: attributed to its total flavonoidal and phenolic contents. Pak J Pharm Sc 2012, 25:463-467.

12. Khan $H$, Saeed M, Gilani AH, Ikram-ul H, Ashraf N, Najeeb-ur R, Haleemi A: Antipyretic and anticonvulsant activity of Polygonatum verticillatum: comparison of rhizomes and aerial parts. Phytother Res 2013, 27:468-471.

13. Khan $H$, Saeed M, Khan MA, Izhar-ul H, Muhammad N, Ghaffar R: Isolation of long chain esters from the rhizome of Polygonatum verticillatum with potent tyrosinase inhibition. Med Chem Res 2013, 22(5):2088-2092.

14. Wang Y, Lu C, Lai G, Cao J, Luo S: A new indolizinone from Polygonatum kingianum. Planta Med 2003, 69:1066-1068.

15. Wang D, Li D, Zhu W, Peng P: A new C-methylated homoisoflavanone and triterpenoid from the rhizomes of Polygonatum odoratum. Nat Prod Res 2009, 23:580-589.

16. Wang D, Li D, Zhu W, Zhang J, Peng P: Steroidal saponins from the rhizomes of Polygonatum odaratum. Nat Prod Res 2009, 23:940-947.

17. Rafi MM, Vastano BC: Identification of a structure specific BCl-2 phosphorylating homoisoflavone molecule from Vietnamese coriander (Polygonatum odoratum) that induces apoptosis and G2/M cell cycle arrest in breast cancer cell lines. Food Chem 2007, 104:332-340.

18. Lu MC, Tsuen HM, Rei WC, Yuan CH, Hsieh CC, Lin YT, Peng WH: Ameliorating effect of emodin, a constitute of Polygonatum multiflorum on cycloheximide-induced impairment of memory consolidation in rats. J Ethnopharmacol 2007, 112:552-556.

19. Antoniuk VO: Purification and properties of lectins of Polygonatum multiflorum [L.] All. and Polygonatum verticillatum [L.] All. Ukr Biokhim Zh 1993, 65:41-8

20. Williamson EM, Okpako DT, Evans FJ: Selection, preparation and pharmacological evaluation of plant material. In Pharmacological methods in phytotherapy research. Volume 1st edition. Chichester: John Wiley and Sons; 1996:15-23.

21. National Research Council: Guide for the care and Use of laboratory animals. Washington: National Academy Press; 1996:1-7.

22. Gilani A, Khan A, Raoof M, Ghayur M, Siddiqui B, Vohra W, Begum S: Gastrointestinal, selective airways and urinary bladder relaxant effects of Hyoscyamus niger are mediated through dual blockade of muscarinic receptors and $\mathrm{Ca}^{2+}$ channels. Fund Clin Pharmacol 2008 22:87-99.

23. Gilani AH, Mandukhail SU, labal J, Yasinzai M, Aziz N, Khan A, Rehman NU: Antispasmodic and vasodilator activities of Morinda citrifolia root extract are mediated through blockade of voltage dependent calcium channels. BMC Complement Altern Med 2010, 10:2.

24. Yim JH, Lee OH, Choi UK, Kim YC: Antinociceptive and anti-Inflammatory effects of ethanolic extracts of Glycine max (L.) Merr and Rhynchosia nulubilis seeds. Int J Mol Sci 2009, 10:4742-4753. doi:10.3390/ijms10114742.

25. Khan S, Mehmood MH, Ali ANA, Ahmed FS, Dar A, Gilani AH: Studies on anti-inflammatory and analgesic activities of betel nut in rodents. J Ethnopharmacol 2011, 135:654-661.

26. Jadrijevi M, Taka M: FT-IR and NMR spectroscopic studies of salicylic acid derivatives. I. Gentisamide-a metabolite of salicylamide. Acta Pharm 2004, 54:163-176.

27. Moghaddam F, Farimani M, Salahvarzi S, Amin G: Chemical constituents of dichloromethane extract of cultivated constituents of dichloromethane extract of cultivated Satureja khuzistanica. Evid Based Compl Altern Med 2007, 4:95-98. doi:10.1093/ecam/nel065.

28. Fleckenstein A: Specific pharmacology of $\mathrm{Ca}^{2+}$ in myocardium, cardiac pacemakers and vascular smooth muscle. Rev Pharmacol Toxicol 1977, 17:149-166.

29. Mathewson HS: Anti-asthmatic properties of calcium antagonists. Respir Care 1985, 30:779-781.

30. Iwata S, Ito S, Iwaki M, Kondo M, Sashio T, Takeda N, Sokabe M, Hasegawa $Y$, Kume H: Regulation of endothelin-1-induced interleukin-6 production by $\mathrm{Ca}^{2+}$ influx in human airway smooth muscle cells. Eur J Pharmacol 2009, 605:15-22.

31. Khan H, Khan MA, Muhammad N, Ashraf N, Gul F, Tariq SA: Antiinflammatory and antioxidant activity of Joshanda partially mediated through inhibition of lipoxygenase. Phytopharmacol 2012, 3:19-28.

32. Jean YP, Michael HP, Steven BA: Prostaglandin E2 synthesis and secretion: the role of PGE2 syntheses. Clin Immunol 2006, 119:229-240.

33. Thorsten JM, Tausch L, Hoernig M, Coste O, Schmidt R, Angioni C, Metzner J, Groesch S, Pergola C, Steinhilber D, Werz O, Geisslinger G: Celecoxib inhibits 5-lipoxygenase. Biochem Pharmacol 2008, 76:862-872.

34. Geroushi A, Auzi AA, Elhwuegi AS, Elzawam F, Elsherif A, Nahar L, Sarker SD: Antiinflammatory sesquiterpenes from the root oil of Ferula hermonis. Phytother Res 2011, 25:774-777.

35. Viji $\mathrm{V}$, Helen A: Inhibition of lipoxygenases and cyclooxygenase-2 enzymes by extracts isolated from Bacopa monniera (L.) Wettst. J Ethnopharmacol 2008, 118(2):305-311.

36. Claria J, Romano M: Pharmacological intervention of cyclooxygenase-2 and 5-lipoxygenase pathways. Impact on inflammation and cancer. Curr Pharm Des 2005, 11:3431-3447.

37. Gupta M, Nath R, Srivastava N, Shanker K, Kishor K, Bhargava K: Anti-inflammatory and antipyretic activities of $\beta$-sitosterol. Planta Med 1980, 39(2):157-163.

38. Gupta R, Sharma AK, Dobhal MP, Sharma MC, Gupta RS: Antidiabetic and antioxidant potential of $\beta$-sitosterol in streptozotocin-induced experimental hyperglycemia. J Diabetes 2011, 3(1):29-37.

39. Sroka Z, Cisowski W: Hydrogen peroxide scavenging, antioxidant and anti-radical activity of some phenolic acids. Food Chem Toxicol 2003, 41(6):753-758.

40. Vane JR: Mechanism of action of nonsteroidal anti-inflammatory drugs. Ameri J Med 1998, 104(3):2S-8S.

41. Lapenna D, Ciofani G, Pierdomenico SD, Neri M, Cuccurullo C, Giamberardino MA, Cuccurullo F: Inhibitory activity of salicylic acid on lipoxygenase-dependent lipid peroxidation. Biochim Biophys Acta (BBA)General Subjects 2009, 1790(1):25-30.

42. Patel B, Welch A, Bingham S, Luben R, Day N, Khaw K, Lomas D, Wareham N: Dietary antioxidants and asthma in adults. Thorax 2006, 61:388.

43. Patrono C, Rocca B: Nonsteroidal antiinflammatory drugs: Past, present and future. Pharmacol Res 2009, 59:285-289.

44. Chaudhary MA, Imran I, Bashir S, Mehmood MH, Rehman NU, Gilani AH: Evaluation of gut modulatory and bronchodilator activities of Amaranthus spinosus Linn. BMC Complement Altern Med 2012, 12(1):166. Epub ahead of print. 
45. Khan H, Khan MA, Gul F, Hussain S, Ashraf N: Anti-inflammatory activity of Heliotropium strigosum in animal models. Toxicol Ind Health 2013. 0748233713491813, first published on July 3, 2013.

46. Rehman NU, Khan AU, Alkharfy KM, Gilani AH: Pharmacological basis for the medicinal use of Lepidium sativum in airways disorders. Evid Based Complement Alternat Med 2012. doi:10.1155/2012/596524.

doi:10.1186/1472-6882-13-197

Cite this article as: Khan et al:: Studies on tracheorelaxant and anti-

inflammatory activities of rhizomes of Polygonatum verticillatum. BMC

Complementary and Alternative Medicine 2013 13:197.

\section{Submit your next manuscript to BioMed Central and take full advantage of:}

- Convenient online submission

- Thorough peer review

- No space constraints or color figure charges

- Immediate publication on acceptance

- Inclusion in PubMed, CAS, Scopus and Google Scholar

- Research which is freely available for redistribution 